\title{
IMPLEMENTASI PEMBELAJARAN SAINS BERBASIS INKUIRI DAN PENGARUHNYA TERHADAP LIFE SKILLS (KECAKAPAN HIDUP) DITINJAU DARI PENGETAHUAN KEISLAMAN MAHASISWA
}

\author{
Ramdhani Sucilestari ${ }^{1}$ \\ 1 Universitas Islam Negeri Mataram, Nusa Tenggara Barat, Indonesia \\ 1sucilestari@uinmataram.ac.id
}

\begin{abstract}
Abstrak
Penelitian ini bertujuan untuk mengetahui pengaruh model pembelajaran inkuiri yang diintegrasikan melalui pengetahuan keislaman terhadap kecakapan hidup mahasiswa. Metode penelitian yang digunakan adalah metode eksperimen semu dengan desain penelitian faktorial $2 \times 2$ melalui prosedur posttest only control group design. Populasi penelitian sejumlah 224 mahasiswa yang terbagi ke dalam 7 kelas yang berbeda. Sampel dalam penelitian berjumlah 64 mahasiswa yang terbagi dalam 2 kelas diambil dengan teknik cluster random sampling. Instrumen penelitian berupa tes pengetahuan keislaman, kecakapan akademik, dan kecakapan personal, angket kecakapan sosial dan performance test kecakapan vokasional. Data hasil penelitian dianalisis dengan Manava dua jalur. Hasil penelitian menunjukkan bahwa: 1) Implementasi model pembelajaran sains berbasis inkuiri berpengaruh terhadap kecakapan hidup mahasiswa, 2) Pengetahuan keislaman tidak berpengaruh terhadap kecakapan hidup mahasiswa, dan 3) Tidak ada pengaruh interaksi implementasi model pembelajaran Sains berbasis inkuiri dan pengetahuan keislaman terhadap kecakapan hidup mahasiswa. Model pembelajaran berbasis inkuiri menjadi alternatif model pembelajaran yang dapat diimplementasikan untuk membina kecakapan hidup mahasiswa di perguruan tinggi khususnya pada pembelajaran sains.
\end{abstract}

Kata kunci: Inkuiri; Pengetahuan Keislaman; Kecakapan Hidup;

\begin{abstract}
This study aims to determine the effect of the inquiry learning model which is integrated through Islamic knowledge on student life skills. The research method used was a quasi-experimental method with a $2 \times 2$ factorial research design through a posttest only control group design procedure. The study population was 224 students divided into 7 different classes. The sample in the study amounted to 64 students divided into 2 classes taken by cluster random sampling technique. The research instruments were in the form of Islamic knowledge tests, academic skills, and personal skills, social skills questionnaires and vocational skills performance tests. Data from the research results were analyzed by two ways Manova. The results showed that: 1) Implementation of inquiry-based science learning
\end{abstract}


models had an effect on student life skills, 2) Islamic knowledge had no effect on student life skills, and 3) There was no interaction effect on the implementation of inquiry-based Science learning models and Islamic knowledge on student life skills. Inquiry-based learning model is an alternative learning model that can be implemented to foster student life skills in higher education especially in science learning.

Keywords: Inquiry; Islamic Knowledge; Life Skills;

\section{PENDAHULUAN}

Pendidikan sains adalah salah satu aspek pendidikan yang digunakan sebagai alat untuk mencapai tujuan pendidikan. Dalam pendidikan sains tersebut tidak hanya terdiri dari fakta, konsep, dan teori yang dapat dihafalkan, tetapi juga terdiri atas kegiatan atau proses aktif menggunakan pikiran dan sikap ilmiah dalam mempelajari gejala alam yang belum diterangkan. Dengan demikian, tuntutan untuk terus menerus memutakhirkan pengetahuan sains menjadi suatu keharusan.

Sains didefinisikan sebagai suatu kumpulan pengetahuan yang tersusun secara sistematis yang ditandai dengan adanya kegiatan ilmiah (Mariana dan Praginda, 2009). Sains berkaitan dengan cara mencari tahu tentang alam secara sistematis. Hal ini yang melandasi salah satu tujuan pembelajaran Sains yaitu mahasiswa memiliki kemampuan melakukan metode ilmiah untuk menumbuhkan kemampuan berpikir, bersikap, dan bertindak ilmiah serta berkomunikasi, sebagai aspek penting dalam menumbuhkan life skill atau kecakapan hidup (Arizona dkk., 2013).

Pendidikan yang berorientasi pada kecakapan hidup merupakan pendidikan yang memberi bekal dasar dan latihan kepada mahasiswa tentang nilai-nilai kehidupan sehari-hari agar mereka mampu, sanggup, dan terampil dalam menjalankan kehidupannya yaitu dapat menjaga kelangsungan hidup dan perkembangannya. Kecakapan hidup dibagi menjadi dua yaitu kecakapan hidup generik dan kecakapan hidup spesifik. Kecakapan hidup generik terdiri atas kecakapan personal (personal skill) dan kecakapan 
Sucilestari, R. (2018). IMPLEMENTASI PEMBELAJARAN SAINS BERBASIS INKUIRI DAN PENGARUHNYA TERHADAP LIFE SKILLS (KECAKAPAN HIDUP) DITINJAU DARI PENGETAHUAN KEISLAMAN MAHASISWA. Jurnal Tatsqif, 16(2). Retrieved from http://journal.uinmataram.ac.id/index.php/tatsqif/article/view/326

sosial (social skill), sementara kecakapan hidup spesifik terbagi menjadi kecakapan akademik dan kecakapan vokasional (Puskur, 2007).

Keempat dimensi kecakapan hidup secara berkelanjutan harus dimiliki oleh setiap mahasiswa. Dominasi pendidikan kecakapan hidup pada jenjang perguruan tinggi ditekankan pada semua ruang lingkup kecakapan hidup. Pada pelaksanaannya, aspek kecakapan hidup dikembangkan atau diintegrasikan dalam kegiatan pembelajaran yang dilakukan sehingga berpengaruh terhadap metode atau model pembelajaran yang digunakan. Oleh sebab itu untuk mempersiapkan lulusan yang memiliki kecakapan hidup perlu dirancang sebuah model dalam pembelajaran Sains yang sesuai untuk pengembangan kecakapan hidup (Mujakir, 2012).

Karakteristik matakuliah pembelajaran Sains menuntut mahasiswa belajar aktif dengan cara menemukan sendiri pengetahuannya melalui pengalaman langsung yang dilakukan melalui kegiatan ilmiah. Hal ini sejalan dengan model pembelajaran inkuiri. Model pembelajaran inkuiri adalah model pembelajaran yang melibatkan mahasiswa aktif dalam proses penemuan pengetahuan melalui kegiatan eksperimen dengan panduan lembar kerja mahasiswa (LKM). Kegiatan eksperimen ala ilmuan memfasilitasi mahasiswa untuk mengkonstruksi kecakapan hidup mereka baik pada ruang lingkup personal, sosial, akademik maupun vokasional. Pada kehidupan nyata, perlu disadari bahwa keempat dimensi kecakakapan hidup tersebut tidak berfungsi secara terpisah. Oleh karena itu, semua ruang lingkup kecakapan hidup yang telah dijelaskan mutlak untuk dimiliki oleh mahasiswa.

Keempat dimensi kecakapan hidup di atas sangat memungkinkan untuk dipupuk melalui ajaran Agama Islam yang luhur. Dalam al-Qur'an maupun alHadits, terdapat norma-norma yang menjelaskan agar umat Islam memiliki sifat-sifat mulia baik secara personal maupun sosial seperti jujur, bekerja keras, tidak putus asa, bertanggung jawab, religius membantu yang lemah, bekerjasama dalam kebaikan, tidak tolong menolong dalam perbuatan yang 
buruk, hormat pada sesama manusia serta sifat-sifat terpuji dan interaksi sosial mulia lainnya.

Dimensi kecakapan akademik menjadi prioritas utama Allah swt. agar hambanya tidak tersesat dengan diturunkan surat pertama yaitu QS. al-'Alaq Ayat 1-5. Budaya literasi yang dibangun oleh Allah swt. menjadi pangkal kesuksesan dunia maupun akhirat. Bahkan nilai dan perkembangan Sains tidak bisa dilepaskan dengan kandungan ajaran Agama Islam. Produk Sains yang kita nikmati sekarang tidak lepas dari anjuran Allah swt. agar manusia senantiasa bertafakur dan mempelajari fenomena alam yang ada. Allah swt. pun menantang manusia untuk menembus ruang angkasa jika mampu sesuai dengan firman-Nya "Hai jama'ah jin dan manusia, jika kamu sanggup menembus (melintasi) penjuru langit dan bumi, maka lintasilah, kamu tidak dapat menembusnya kecuali dengan kekuatan" (QS. Arrahman: 33). Beberapa ahli tafsir menafsirkan kata "sulthaan" dengan ilmu pengetahuan. Ini merupakan contoh kecil yang menyiratkan kemuliaan ajaran Islam dalam membina kecakapan hidup mahasiswa. Oleh karena itu, pengetahuan keislaman sangat perlu menjadi tinjauan dalam penelitian ini untuk melihat pengaruh pembelajaran sains berbasis inkuiri terhadap kecakapan hidup mahasiswa.

\section{LANDASAN TEORI}

\section{Pembelajaran Sains Berbasis Inkuiri}

Inkuiri berasal dari bahasa Inggris yaitu inquiry yang diartikan sebagai proses bertanya dan mencari tahu jawaban terhadap pertanyaan ilmiah yang diajukan. Inkuiri adalah proses untuk memperoleh dan mendapatkan informasi dengan melakukan observasi dan atau eksperimen untuk mencari jawaban atau memecahkan masalah terhadap pertanyaan atau rumusan masalah dengan menggunakan kemampuan berpikir kritis dan logis (Amri dkk., 2010). Inkuiri merupakan suatu rangkaian kegiatan pembelajaran yang melibatkan secara maksimal seluruh kemampuan peserta didik untuk mencari dan menyelidiki secara sistematis, kritis, dan logis sehingga mereka 
Sucilestari, R. (2018). IMPLEMENTASI PEMBELAJARAN SAINS BERBASIS INKUIRI DAN PENGARUHNYA TERHADAP LIFE SKILLS (KECAKAPAN HIDUP) DITINJAU DARI PENGETAHUAN KEISLAMAN MAHASISWA. Jurnal Tatsqif, 16(2). Retrieved from http://journal.uinmataram.ac.id/index.php/tatsqif/article/view/326

dapat menemukan sendiri pengetahuan, sikap dan keterampilan sebagai wujud adanya perubahan perilaku (Hanafiah dan Suhana, 2010).

Model pembelajaran inkuiri merupakan suatu model pembelajaran yang dikembangkan agar mahasiswa menemukan dan menggunakan berbagai sumber informasi dan ide-ide untuk meningkatkan pemahaman mereka tentang masalah, topik, atau isu tertentu. Inkuiri menuntut mahasiswa memiliki kemampuan untuk melakukan serangkaian investigasi, eksplorasi, pencarian, eksperimen, penelusuran, dan penelitian (Abidin, 2014). Model pembelajaran inkuiri sebagai rangkaian kegiatan pembelajaran yang menekankan pada proses berpikir mahasiswa secara kritis dan analitis untuk mencari dan menemukan sendiri jawaban dari suatu masalah yang dipertanyakan (Sanjaya, 2014).

Tahap-tahap pembelajaran inkuiri terbimbing menurut Eggen \& Kauchak (2012) yaitu: menyajikan pertanyaan atau masalah, membuat hipotesis, merancang percobaan, melakukan percobaan, mengumpulkan dan menganalisis data, dan membuat kesimpulan (Eggen \& Kauchak, 2012). Pembelajaran berbasis inkuiri dalam penelitian ini diadaptasi dari Arizona (2013) yang dituangkan dalam lembar kerja mahasiswa (LKM) dengan tahapan yaitu: mengajukan pertanyaan dan permasalahan, merumuskan hipotesis, melakukan eksperimen, mengumpulkan data, menganalisis data, dan membuat kesimpulan.

Model pembelajaran inkuiri memiliki beberapa keunggulan yaitu: mendorong mahasiswa untuk berpikir dan bekerja keras atas inisiatifnya sendiri, bersikap obyektif, jujur, dan terbuka; mengembangkan bakat atau kecakapan individu; serta mendorong mahasiswa untuk merumuskan hipotesisnya sendiri (Roestiyah, 2012). Adapun beberapa kelemahan pembelajaran inkuiri sebagaimana yang diungkapkan oleh Suyadi (2013) yaitu: mahasiswa akan bingung dan tidak terarah jika dosen kurang spesifik merumuskan pertanyaan untuk memecahkan permasalahan secara sistematis; pembelajaran inkuiri membutuhkan waktu yang lama, inkuiri 
Sucilestari, R. (2018). IMPLEMENTASI PEMBELAJARAN SAINS BERBASIS INKUIRI DAN PENGARUHNYA TERHADAP LIFE SKILLS (KECAKAPAN HIDUP) DITINJAU DARI PENGETAHUAN KEISLAMAN MAHASISWA. Jurnal Tatsqif, 16(2). Retrieved from http://journal.uinmataram.ac.id/index.php/tatsqif/article/view/326

sukar dikembangkan dengan baik jika jumlah mahasiswa relatif banyak,; serta, inkuiri sulit diimplementasikan selama kriteria keberhasilan belajar ditentukan oleh kemampuan mahasiswa dalam menguasai materi.

\section{Pengetahuan Keislaman}

Islam merupakan agama Allah swt. yang diperintahkan-Nya untuk mengajarkan tentang pokok-pokok serta peraturan-peraturannya kepada Nabi Muhammad saw. dan menugaskannya untuk menyampaikan agama tersebut kepada seluruh manusia dengan mengajak mereka untuk memeluknya. Salah satu ciri yang membedakan Islam dengan agama yang lainnya adalah penekanannya terhadap ilmu (sains). Al-Qur'an dan AlSunnah mengajak kaum muslimin untuk mencari dan mendapatkan ilmu dan kearifan, serta menempatkan orang-orang yang berpengetahuan pada derajat yang tinggi (Hasyim, 2013).

Ilmu pengetahuan merupakan hal yang tidak dapat dipisahkan dari ajaran agama Islam. Pengetahuan ilmiah diperoleh melalui indra, akal, dan hati/intuitif yang bersumber dari alam fisik dan alam metafisik. Ilmu pengetahuan dalam Islam dicapai melalui tiga sumber/alat; indra, akal budi, dan hati, pengetahuan ilmiah hanya bisa diraih melalui indra dan akal. Sains hanya membatasi diri pada objek-objek empiris, fisik, materi, dan eksternal. Dengan kata lain, sains hanya akan berurusan dengan objek-objek yang teramati oleh indra (Latief, 2014).

\section{Kecakapan Hidup}

Kecakapan hidup adalah urutan pilihan yang memperkuat kehidupan psikologis yang dibuat seseorang dalam bidang keterampilan yang spesifik (Nelson, 1997). Kecakapan hidup merupakan pengembangan diri untuk bertahan hidup, tumbuh, dan berkembang, memiliki kemampuan untuk berkomunikasi dan berhubungan baik secara individu, kelompok maupun melalui sistem dalam menghadap situasi tertentu (Depdiknas, 2003).

Kecakapan hidup dibagi menjadi dua yaitu: kecakapan hidup generik dan kecakapan hidup spesifik. Kecakapan hidup generik adalah kecakapan 
Sucilestari, R. (2018). IMPLEMENTASI PEMBELAJARAN SAINS BERBASIS INKUIRI DAN PENGARUHNYA TERHADAP LIFE SKILLS (KECAKAPAN HIDUP) DITINJAU DARI PENGETAHUAN KEISLAMAN MAHASISWA. Jurnal Tatsqif, 16(2). Retrieved from http://journal.uinmataram.ac.id/index.php/tatsqif/article/view/326

yang harus dimiliki oleh setiap manusia Kecakapan hidup spesifik adalah kecakapan yang diperlukan seseorang untuk menghadapi problema bidang khusus seperti pekerjan/kegiatan dan atau keadaan tertentu. Kecakapan hidup generik terdiri atas kecakapan personal (personal skill) dan kecakapan sosial (social skill), sementara kecakapan hidup spesifik dibagi lagi menjadi kecakapan akademik dan kecakapan vokasional (Puskur, 2007).

Kecakapan personal adalah kecakapan yang dimiliki oleh seseorang untuk memiliki kesadaran atas eksistensi dirinya dan kesadaran akan potensinya. Kecakapan personal terdiri atas kecakapan mengenal diri sendiri dan kecakapan berpikir. Kecakapan mengenal diri meliputi kesadaran sebagai makhluk Tuhan, kesadaran eksistensi diri, dan kesadaran akan potensi diri. Mengenal diri akan mendorong seseorang untuk beribadah sesuai agamanya, berlaku jujur, bekerja keras, disiplin, terpercaya, toleran terhadap sesama, suka menolong serta memelihara lingkungan. Sedangkan kecakapan berpikir mencakup kecakapan menggali dan menemukan informasi, mengolah informasi, mengambil keputusan dan memecahkan masalah secara kreatif (Anwar, 2006).

Sebagai makhluk sosial yang tinggal dalam masyarakat, mahasiswa sangat memerlukan kecakapan berkomunikasi secara lisan maupun tulisan. Dalam realitasnya komunikasi lisan ternyata tidak mudah dilakukan. Demikian juga dengan kecakapan berkomunikasi secara tertulis, dalam hal ini diperlukan kecakapan cara menyampaikan pesan secara tertulis dengan pilihan kata, kalimat, tata bahasa, dan aturan lainnya agar mudah dipahami (Puskur, 2007). Kecakapan sosial atau kecakapan antar pribadi (interpersonal skill) meliputi kecakapan berkomunikasi dengan empati dan kecakapan bekerja-sama (collaboration skill). Pada kecakapan komunikasi seperti empati, sikap penuh pengertian, dan seni berkomunikasi dua arah perlu ditekankan, karena berkomunikasi bukan sekedar menyampaikan pesan, tetapi isi dan sampainya pesan disertai dengan kesan baik yang akan menumbuhkan hubungan harmonis. 
Kecakapan akademik mencakup antara lain kecakapan mengidentifikasi variabel dan menjelaskan hubungannya dengan suatu fenomena tertentu, merumuskan hipotesis terhadap suatu rangkaian kejadian, serta merancang dan melaksanakan penelitian untuk membuktikan suatu gagasan atau keingintahuan. Kecakapan akademik sering juga disebut kemampuan berpikir ilmiah dan lebih mengarah kepada kegiatan bersifat keilmuan (Puskur, 2007).

Kecakapan vokasional sering diistilahkan dengan kecakapan kejuruan, artinya kecakapan yang dikaitkan dengan bidang pekerjaan tertentu. Implementasi dalam menumbuhkan kembangakan kecakapan vokasional terhadap mahasiswa dapat dimulai dari kecakapan mereka dalam mengenal suatu alat atau bahan, menggunakan alat, dan mengoperasikan alat yang telah dibuat (Wuryastuti dan Ni'mah, 2013).

\section{METODE}

Jenis penelitian ini adalah eksperimen semu yaitu untuk melihat pengaruh implementasi pembelajaran berbasis inkuiri terhadap kecakapan hidup ditinjau dari pengetahuan keislaman mahasiswa. Pendekatan penelitian menggunakan pendekatan kuantitatif dengan desain penelitian faktorial 2x2 melalui prosedur posttest only control group design. Populasi penelitian sejumlah 224 mahasiswa yang terbagi ke dalam 7 kelas yang berbeda. Sampel dalam penelitian berjumlah 64 mahasiswa yang terbagi dalam 2 kelas diambil dengan teknik cluster random sampling.

Instrumen penelitian berupa tes tulis, angket dan performance test yang sudah divalidasi. Data pengetahuan keislaman, data kecakapan akademik dan data kecakapan personal diperoleh melalui pemberian tes. Data kecakapan sosial diperoleh melalui pemberian angket, sedangkan data kecakapan vokasional diperoleh dari performance test.

Data kecakapan hidup mahasiswa dianalisis secara deskriptif dan statistik dengan uji Manova dua jalur (Two Way Manova). Analisis uji Manova 
Sucilestari, R. (2018). IMPLEMENTASI PEMBELAJARAN SAINS BERBASIS INKUIRI DAN PENGARUHNYA TERHADAP LIFE SKILLS (KECAKAPAN HIDUP) DITINJAU DARI PENGETAHUAN KEISLAMAN MAHASISWA. Jurnal Tatsqif, 16(2). Retrieved from http://journal.uinmataram.ac.id/index.php/tatsqif/article/view/326

diawali dengan uji normalitas dan uji homogenitas data sebagai prasyarat uji statistik parametrik. Analisis data dibantu dengan SPSS 18 for windows.

\section{HASIL DAN PEMBAHASAN}

Hasil penelitian menunjukkan bahwa: 1) implementasi model pembelajaran Sains berbasis inkuiri berpengaruh terhadap kecakapan hidup mahasiswa, 2) Pengetahuan keislaman tidak berpengaruh terhadap kecakapan hidup mahasiswa, dan 3) Tidak ada pengaruh interaksi implementasi model pembelajaran Sains berbasis inkuiri dan pengetahuan keislaman terhadap kecakapan hidup mahasiswa. Berikut penjabaran pada setiap aspek kecakapan hidup meliputi kecakapan akademik, kecakapan vokasional, kecakapan personal dan kecakapan sosial.

\section{Data Kecakapan Hidup Mahasiswa}

Penilaian pada aspek kecakapan akademik mahasiswa yaitu kecakapan berpikir ilmiah. Penilaian kecakapan vokasional terkait dengan kecakapan mahasiswa dalam mengenal bahan/alat, menggunakan alat/bahan pada kegiatan eksperimen. Penilaian kecakapan personal mahasiswa meliputi kecakapan mengenal diri (religius, kejujuran, kedisplinan, dan tanggung jawab) dan kemampuan berpikir rasional (kemampuan verbal, kemampuan matematis, kemampuan logis dan kemampuan analitis). Penilaian pada aspek kecakapan sosial mahasiswa yakni kecakapan berkomunikasi baik secara lisan maupun tulisan dan kecakapan berkerjasama.

Penilaian pada semua aspek kecakapan hidup mahasiswa menunjukkan bahwa kecakapan hidup pada kelas eksperimen secara rerata lebih tinggi daripada kelas kontrol. Data kecakapan akademik selengkapnya dapat dilihat pada Tabel 1.

Tabel 1. Deskripsi Data Kecakapan Hidup Mahasiswa

\begin{tabular}{ccccccc}
\hline \multirow{2}{*}{ Kecakapan Hidup } & \multirow{2}{*}{ Kelas } & \multirow{2}{*}{ N } & \multicolumn{4}{c}{ Nilai } \\
\cline { 4 - 6 } & & Min & Max & Rerata & Stdev \\
\hline Kecakapan Akademik & Eksperimen & 32 & 70,00 & 100,00 & 92,50 & 8,68 \\
& Kontrol & 32 & 70,00 & 100,00 & 75,94 & 6,15 \\
Kecakapan Vokasional & Eksperimen & 32 & 86,67 & 100,00 & 96,18 & 3,62 \\
\hline
\end{tabular}


Sucilestari, R. (2018). IMPLEMENTASI PEMBELAJARAN SAINS BERBASIS INKUIRI DAN PENGARUHNYA TERHADAP LIFE SKILLS (KECAKAPAN HIDUP) DITINJAU DARI PENGETAHUAN KEISLAMAN MAHASISWA. Jurnal Tatsqif, 16(2). Retrieved from http://journal.uinmataram.ac.id/index.php/tatsqif/article/view/326

\begin{tabular}{lcccccc}
\hline & Kontrol & 32 & 75,56 & 100,00 & 87,50 & 5,29 \\
Kecakapan Personal & Eksperimen & 32 & 20,00 & 92,00 & 50,75 & 12,95 \\
& Kontrol & 32 & 16,00 & 64,00 & 48,00 & 11,72 \\
Kecakapan Sosial & Eksperimen & 32 & 78,00 & 98,67 & 85,08 & 5,57 \\
& Kontrol & 32 & 55,33 & 94,00 & 79,49 & 9,09 \\
\hline
\end{tabular}

\section{Data Kecakapan Hidup Mahasiswa Ditinjau Dari Pengetahuan}

\section{Keislaman}

Hasil kecakapan akademik mahasiswa pada kelompok mahasiswa yang memiliki pengetahuan keislaman tinggi secara rerata lebih tinggi daripada mahasiswa yang memiliki pengetahun keislaman rendah pada semua aspek kecakapan hidup, kecuali pada aspek kecakapan vokasional. Data kecakapan hidup ditinjau dari pengetahuan keislaman selengkapnya dapat dilihat pada Tabel 2.

Tabel 2. Deskripsi Data Kecakapan Hidup Mahasiswa Ditinjau Dari Pengetahuan Keislaman

\begin{tabular}{lcccccc}
\hline \multirow{2}{*}{ Kecakapan Hidup } & Pengetahuan & \multirow{2}{*}{$\mathrm{N}$} & \multicolumn{5}{c}{ Nilai } \\
\cline { 5 - 7 } & Keislaman & & Min & Max & Rerata & Stdev \\
\hline Kecakapan Akademik & Tinggi & 33 & 70,00 & 100,00 & 84,70 & 11,23 \\
& Rendah & 31 & 70,00 & 100,00 & 83,71 & 11,32 \\
Kecakapan Vokasional & Tinggi & 33 & 75,56 & 100,00 & 91,58 & 6,18 \\
& Rendah & 31 & 77,78 & 100,00 & 92,11 & 6,46 \\
Kecakapan Personal & Tinggi & 33 & 16,00 & 64,00 & 49,45 & 11,87 \\
& Rendah & 31 & 20,00 & 92,00 & 49,29 & 12,99 \\
Kecakapan Sosial & Tinggi & 33 & 58,67 & 98,67 & 84,10 & 7,25 \\
& Rendah & 31 & 20,00 & 92,00 & 80,37 & 8,40 \\
\hline
\end{tabular}

\section{Hasil Uji Hipotesis}

Uji prasyarat statistik sebelum dilakukan uji hipotesis yaitu uji normalitas dan uji homogenitas pada data kecakapan hidup mahasiswa. Hasil uji normalitas data dengan uji Kolmogorov-Smirnov menunjukkan bahwa data kecakapan hidup mahasiswa baik pada kelas eksperimen maupun kelas kontrol berdistribusi normal dengan ketentuan $\mathrm{P}>0,05$. Hasil uji homogenitas data dengan uji Levene menunjukkan bahwa seluruh data kecakapan hidup baik pada kelas eksperimen maupun kelas kontrol memiliki nilai $\mathrm{P}>0,05$ artinya data memiliki varians yang homogen.

Uji hipotesis data kecakapan hidup mahasiswa dengan Manova dua jalur (twoway Manova) karena memenuhi uji prasyarat yaitu data 
terdistribusi normal dan memiliki varian yang homogen. Hasil uji hipotesis data kecakapan hidup dijabarkan sebagai berikut.

a. Kecakapan Akademik

Hasil uji hipotesis menginterpretasikan bahwa model pembelajaran inkuiri berbengaruh terhadap kecakapan akademik $(\mathrm{P}<0,05)$, namun pengetahuan keislaman tidak berpengaruh terhadap kecakapan akademik mahasiswa $(\mathrm{P}>0,05)$. Hasil analisis interaksi model pembelajaran dan pengetahuan keislaman tidak berpengaruh terhadap kecakapan akademik mahasiswa $(\mathrm{P}>0,05)$.

b. Data Kecakapan Vokasional

Hasil uji hipotesis menyatakan bahwa model pembelajaran inkuiri berbengaruh terhadap kecakapan vokasional $(\mathrm{P}<0,05)$, namun pengetahuan keislaman tidak berpengaruh terhadap kecakapan vokasional mahasiswa $(\mathrm{P}>0,05)$. Hasil analisis interaksi model pembelajaran dan pengetahuan keislaman tidak berpengaruh terhadap kecakapan vokasional mahasiswa $(\mathrm{P}>0,05)$.

c. Data Kecakapan Personal

Hasil uji hipotesis menunjukkan bahwa model pembelajaran inkuiri dan pengetahuan keislaman serta interaksi keduanya tidak berbengaruh terhadap kecakapan personal mahasiswa $(\mathrm{P}>0,05)$.

d. Data Kecakapan Sosial

Hasil uji hipotesis menginterpretasikan bahwa model pembelajaran inkuiri berbengaruh terhadap kecakapan sosial $(\mathrm{P}<0,05)$, demikian juga pengetahuan keislaman berpengaruh terhadap kecakapan sosial mahasiswa $(\mathrm{P}<0,05)$. Hasil analisis interaksi model pembelajaran dan pengetahuan keislaman tidak berpengaruh terhadap kecakapan sosial mahasiswa $(\mathrm{P}>0,05)$.

Pendidikan yang berorientasi pada kecakapan hidup merupakan pendidikan yang memberi bekal dasar dan latihan tentang nilai-nilai kehidupan sehari-hari agar mahasiswa mampu, sanggup, dan terampil dalam 
Sucilestari, R. (2018). IMPLEMENTASI PEMBELAJARAN SAINS BERBASIS INKUIRI DAN PENGARUHNYA TERHADAP LIFE SKILLS (KECAKAPAN HIDUP) DITINJAU DARI PENGETAHUAN KEISLAMAN MAHASISWA. Jurnal Tatsqif, 16(2). Retrieved from http://journal.uinmataram.ac.id/index.php/tatsqif/article/view/326

menjalankan kehidupannya. Pendidikan kecakapan hidup dipupuk melalui pembelajaran sains berbasis inkuiri. Pembelajaran sains dapat mengembangkan sikap-sikap khusus terhadap alam sekitar, misalnya rasa ingin tahu tentang alam, antusiasme terhadap pengetahuan ilmiah dan metodenya. Pembelajaran sains juga meneguhkan dan memperkuat rasa tanggung jawab, kesediaan untuk bekerja sama, toleransi, rasa percaya diri dan menghargai orang lain, kebebasan, dapat dipercaya, dan kejujuran intelektual.

Pendidikan kecakapan hidup diberikan kepada mahasiswa sehingga mereka lebih memaknai tentang hakikat belajar yang sesungguhnya dan memberikan bekal untuk hidup secara bermakna. Kecakapan hidup perlu dilatih pada proses pembelajaran. Pembelajaran berbasis inkuiri merupakan salah satu model pembelajaran dengan lingkungan belajar yang mendorong mahasiswa membangun pengetahuan dan kecakapan hidup. Pembelajaran berbasis inkuiri dalam penelitian ini berlangsung secara kolaboratif dalam kelompok. Tiap kelompok terdiri dari 5-6 orang mahasiswa. Hal ini memungkinkan pengembangan kognitif melalui interaksi antarpersonal pada setiap kelompok.

Model pembelajaran inkuiri berpengaruh terhadap kecakapan hidup mahasiswa. Pengaruh model pembelajaran inkuiri ini terlihat pada aspek kecakapan hidup yaitu kecakapan sosial, kecakapan akademik dan kecakapan vokasional namun tidak pada aspek kecakapan personal. Pembelajaran berbasis inkuiri merupakan model pembelajaran yang memperhatikan pemahaman mahasiswa. Mahasiswa melakukan eksplorasi, penilaian, interpretasi, dan mensintesis informasi melalui cara yang bermakna. Melalui pembelajaran sains berbasis inkuiri kecakapan hidup mahasiswa dilatih sehingga cakap dalam menghadapi permasalahan-permasalahan yang ada pada dunia nyata khususnya dalam proses pembelajaran.

Pada kegiatan eksperimen, mahasiswa dilatih untuk menyiapkan alat dan bahan, melaksanakan percobaan sesuai dengan prosedur yang ada pada 
Sucilestari, R. (2018). IMPLEMENTASI PEMBELAJARAN SAINS BERBASIS INKUIRI DAN PENGARUHNYA TERHADAP LIFE SKILLS (KECAKAPAN HIDUP) DITINJAU DARI PENGETAHUAN KEISLAMAN MAHASISWA. Jurnal Tatsqif, 16(2). Retrieved from http://journal.uinmataram.ac.id/index.php/tatsqif/article/view/326

LKM, mengolah data dan menganalisisnya, menginterpretasi data sekaligus mengkomunikasikan hasil percobaan yang sudah mereka lakukan secara berkelompok. Langkah-langkah percobaan pada kegiatan eksperimen melatih kecakapan vokasional mahasiswa menjadi lebih baik. Kemampuan berkomunikasi tulisan terlihat dari kemampuan mereka dalam membuat laporan hasil percobaan yang sudah mereka lakukan pada proses pembelajaran.

Pemberian kecakapan hidup kepada mahasiswa benar-benar merefleksikan nilai-nilai kehidupan nyata. Dengan bekal kecakapan sosial, seseorang akan dapat menjalani kehidupan dengan baik di tengah makin krisisnya budaya santun dalam berkomunikasi dan mengikisnya etika serta kesopanan dalam berinteraksi antar sesama (Arizona dkk, 2013).

Model pembelajaran inkuiri menjadi alternatif model pembelajaran yang dapat diimplementasikan untuk membina kecakapan hidup mahasiswa di perguruan tinggi hususnya pada pembelajaran yang berkaitan dengan sains. Namun aspek pengetahuan keislaman tidak menunjukkan efek yang signifikan terhadap kecakapan hidup mahasiswa, walaupun secara rerata mahasiswa yang memiliki pengetahuan keislaman yang tinggi lebih baik dalam meraih nilai kecakapan hidup. Berdasarkan hasil deskripsi data, mahasiswa yang belajar dengan model pembelajaran inkuiri dan memiliki pengetahuan keislaman yang tinggi memiliki nilai kecakapan hidup yang lebih baik dibandingkan mahasiswa yang belajar secara konvensional dan memiliki pengetahuan keislaman tinggi atau rendah. Hal ini menafsirkan perlu adanya sinergi antara pembelajaran inkuiri dengan peningkatan keislaman mahasiswa. Walaupun berdasarkan uji hipotesis tidak berpengaruh secara signifikan.

Model pembelajaran inkuiri merupakan salah satu model pembelajaran yang inovatif yang tepat digunakan dalam pembelajaran sains karena dapat mengembangkan kemampuan siswa untuk memahami dan memperoleh pengetahuan melalui cara berpikir sistematis dan ilmiah. Inkuiri lebih 
mengutamakan aktivitas mahasiswa dalam proses kegiatan pembelajaran. Mahasiswa membangun pengetahuan dan pemahaman tentang bagaimana seorang ilmuwan bekerja. Langkah-langkah dalam model inkuiri terbimbing melatih kecakapan hidup mahasiswa. Selama menempuh pembelajaran sains menggunakan model inkuiri mahasiswa terlatih untuk menyelesaikan persoalan yang mereka hadapi dalam pembelajaran. Mereka melakukan serangkaian kegiatan percobaan. Kecakapan hidup mereka dilatih pada proses pembelajaran.

Hasil penelitian ini diperkuat dengan hasil penelitian yang dilakukan oleh Sucilestari dan Arizona (2018) yang menyatakan bahwa kecakapan hidup mahasiswa terlatih ketika mereka melakukan serangkaian kegiatan eksperimen dalam proses pembelajaran sains. Model pembelajaran inkuiri tidak hanya mengembangkan kemampuan intelektual tetapi seluruh potensi yang ada, termasuk pengembangan emosional dan keterampilan berpikir. Inkuiri banyak mengarahkan dan memberikan petunjuk baik lewat prosedur yang lengkap dan pertanyaan-pertanyaan pengarahan selama proses inkuiri. Dosen banyak memberikan pertanyaan di sela-sela proses, sehingga kesimpulan lebih cepat dan mudah diambil. Model pembelajaran inkuiri merupakan suatu model yang menuntun mahasiswa dalam mengembangkan kemampuan berpikir dan menekankan sikap ilmiah serta keterampilan proses sains sehingga meningkatkan literasi mereka terhadap sains.

\section{KESIMPULAN}

Kesimpulan berdasarkan hasil penelitian yaitu:

1. Implementasi model pembelajaran Sains berbasis inkuiri berpengaruh terhadap kecakapan hidup mahasiswa,

2. Pengetahuan keislaman tidak berpengaruh terhadap kecakapan hidup mahasiswa, dan 
3. Tidak ada pengaruh interaksi implementasi model pembelajaran Sains berbasis inkuiri dan pengetahuan keislaman terhadap kecakapan hidup mahasiswa.

Model pembelajaran berbasis inkuiri menjadi alternatif model pembelajaran yang dapat diimplementasikan untuk membina kecakapan hidup mahasiswa di perguruan tinggi khususnya pada pembelajaran sains.

\section{DAFTAR PUSTAKA}

Abidin, Y. (2014). Desain Pembelajaran dalam Konteks Kurikulum 2013. Bandung: PT Refika Aditama.

Amri, S., dan Ahmadi, I.K. (2010.) Proses Pembelajaran Kreatif dan Inovatif dalam Kelas. Jakarta: PT. Prestasi Pustakaraya.

Anwar. (2006). Pendidikan Kecakapan Hidup (Life Skill Education). Bandung: Alfabeta.

Arizona, K. (2013). Pengaruh Media Tiga Dimensi Kemagnetan Berbasis Inkuiri melalui Strategi Koopertif terhadap Kecakapan Sosial, Sikap Ilmiah dan Hasil Belajar Kognitif Fisika Peserta didik Kelas IX. Tesis S2. Mataram: Universitas Mataram.

Arizona, K., Harjono, A., dan Jufri, A.W. (2013). Pengaruh Implementasi Media Tiga Dimensi Kemagnetan Berbasis Inkuiri (MTDKBI) melalui Strategi Kooperatif terhadap Kecakapan Sosial. Jurnal Erudio, 1(2), 134-138.

Depdiknas, T.B.E. (2003). Pola Pelaksanaan Kecakapan Hidup melalui Pendekatan Kecakapan Hidup melalui Pendidikan Berbasis Luas. Surabaya: SIC.

Eggen, P. dan Kauchak, D. (2012). Strategi dan Model Pembelajaran Mengajarkan Konten dan Keterampilan Berpikir Edisi Keenam (Penerjemah: Satrio Wahono). Jakarta: Indeks.

Gulo, W. (2008). Strategi Belajar Mengajar. Jakarta: Grasindo.

Hanafiah dan Suhana, C. (2010). Konsep Strategi Pembelajaran. Bandung: Refika Aditama.

Hasyim, B. (2013). Islam dan Ilmu Pengetahuan (Pengaruh Temuan Sains terhadap Perubahan Islam). Jurnal Dakwah Tabligh, 14 (1), 127-139. 
Mariana, I. M. A., dan Praginda, W. (2009). Hakikat IPA dan Pendidikan IPA: Untuk Guru SD. Bandung: PPPPTK IPA.

Mujakir. (2012). Pengembangan Life Skill dalam Pembelajaran Sains. Jurnal Ilmiah DIDAKTITA, XIII (1), 1-13.

Nelson-Jones, R. (1997). Practical Counseling and Helping Skills, Texts and Exercises for the Life Skills Counseling Model. Fourth Edition. London: British Library Cataloging in Publication Data.

Puskur. (2007). Pengembangan Model Pendidikan Kecakapan Hidup. Jakarta: Balitbang Depdiknas.

Roestiyah. (2012). Strategi Belajar Mengajar. Jakarta: PT Rineka Cipta.

Sanjaya, W. (2014). Strategi Pembelajaran: Berorientasi Standar Proses Pendidikan. Jakarta: Kencana Prenadamedia Group.

Sucilestari, R dan Arizona, K. (2018). Pengaruh Project Based Learning pada Matakuliah Elektronika Dasar terhadap Kecakapan Hidup Mahasiswa Prodi Tadris Fisika UIN Mataram. KONSTAN Jurnal Fisika dan Pendidikan Fisika, 3 (1), 26-35

Suyadi. (2013). Strategi Pembelajaran Pendidikan Karakter. Bandung: PT Remaja Rosdakarya.

Wuryastuti, S. dan Ni'mah, I. (2013). Model Pembelajaran Berbasis Lingkungan untuk Meningkatkan Kecakapan Hidup Mahasiswa melalui Pembuatan Kompor Biogas. EduHumaniora, 5(2), 113-120. 